\title{
KONSEP PENDIDIKAN ISLAM DALAM KITAB FATHUL BAARI
}

\author{
Minggusta Juliadarma \\ IAIN Ternate \\ minggustajuliadharma@gmail.com
}

\begin{abstract}
The concept of Islamic education is absolutely necessary in forming Muslims who are pious, noble and have good cognitive abilities. For this reason, many Islamic thinkers try to formulate the concept of Islamic education as a whole which can be used as a reference in fostering the younger generation of Islam. Islamic thinkers include: Ibn Hazm, al-Ghazali, an-Nahlawi, Naguib al-Attas and others. In this paper, the author tries to present other nuances from a different perspective, the author tries to uncover the concept of Islamic education According to the hadith scholars, namely Ibn Hajar alAsqalani in the book Fathul Baari. The research in this paper aims to: (1) To know the concept of Islamic education in the book Fathul Baari, and (2) To find out the differences in the concept of Islamic education in the book Fathul Baari with the concept of other Islamic education. the concept of Islamic education in the book contains the definition of education, the position of science in Islamic education, educators and their duties, and methods of education.
\end{abstract}

Keywords: concept of Islamic education, book Fathul Baari, Ibnu Hajar al-Asqalani.

\begin{abstract}
Abstrak
Konsep pendidikan Islam mutlak diperlukan dalam membentuk muslim yang bertakwa, berakhlak mulia dan memiliki kemampuan kognitif yang baik. Untuk itu banyak sekali pemikir-pemikir Islam mencoba untuk merumuskan konsep pendidikan Islam secara utuh yang dapat dijadikan acuan dalam pembinaan generasi muda Islam. Pemikir-pemikir Islam itu diantaranya: Ibnu Hazm, al- Ghazali, anNahlawi, Naquib al-Attas dan yang lainnya. Dalam tulisan ini, penulis mencoba menghadirkan nuansa lain dari sudut pandang yang berbeda, yaitu penulis mencoba mengungkap konsep pendidikan Islam menurut ulama hadits, yaitu Ibnu Hajar al-Asqalani dalam kitab Fathul al-Baari. Penelitian dalam karya tulis ini bertujuan untuk: (1) Untuk mengetahui konsep pendidikan Islam dalam kitab Fathul Baari, dan (2) Untuk mengetahui perbedaan konsep pendidikan Islam dalam
\end{abstract}


kitab Fathul Baari dengan konsep pendidikan Islam yang lain. konsep pendidikan islam dalam kitab Fathul Baari ini berisi tentang definisi pendidikan, kedudukan ilmu dalam pendidikan Islam, pendidik dan tugas- tugasnya, penuntut ilmu dan adab-adab dalam menuntut ilmu dan metode pendidikan.

Kata Kunci : Konsep pendidikan Islam, kitab Fathul Baari, Ibnu Hajar alAsqalani.

\section{Pendahuluan}

Lemahnya

paradigma

pendidikan Islam dianggap belum memiliki paradigma yang mapan. Teori-teori ilmiah yang menyentuh pada pendidikan Islam dirasa masih kurang. Akibatnya, meskipun hanya bersifat deskriptif, konsep pendidikan Islam nampak tidak memiliki pola pikir yang jelas dalam menafsirkan ayat-ayat al-Our'an dan al-Hadits yang berhubungan dengan masalah kependidikan. Sehingga hal itu sulit untuk diteliti secara ilmiah. Dari kondisi pendidikan Islam yang demikian, sebagian kalangan muslim menganggap bahwa konsep pendidikan Islam masih belum menentu dan cenderung sporadis.

Pada satu sisi konsep pendidikan Islam dituntut untuk mengacu pada al-Our'an dan alHadits, tetapi di sisi lain kedua sumber pokok ajaran Islam itu baru dapat ditafsirkan sebagai teori pendidikan Islam tanpa melihat konteks filsafatnya. Oleh karena itu, dalam praktek pendidikan Islam selama ini baru sekedar mengambil alih dari teori-teori pendidikan Barat yang dikonsultasikan dengan ayatayat al-Our'an dan al-Hadits.

Berangkat dari problematika tersebut, maka perlu untuk mengeksplorasi konsep pendidikan Islam dari sudut pandang yang lain dan jarang disentuh oleh para penulis maupun para pakar pendidikan. Hadits merupakan sumber hukum Islam kedua setelah al-Qur'an yang sangat layak dijadikan pedoman dalam mencari segala informasi yang dibutuhkan dalam problematika kehidupan, termasuk di dalamnya problematika pendidikan. Banyak sekali hadits-hadits yang berkaitan dengan pendidikan dan yang mengandung aspek-aspek pendidikan. Diantara hadits-hadits tersebut akan kita temui hadits shahih dan hadits dhaif , oleh karena itu, untuk menghindari hadits dhaif tersebut, penulis sengaja memilih kitab Fathul Baari yang berisi haditshadits shahih yang diriwayatkan oleh imam Bukhari.

Pada penulisan mengenai kosep pendidikan Islam ini, akan 
diketahui bagaimana konsep mengandung unsur pendidikan pendidikan Islam berdasarkan pemahaman dan inti sari dari haditshadits Nabi yang mengandung unsur pendidikan Islam, terutama haditshadits yang tertulis dalam kitab Shahih Bukhari. Salah satu kitab yang khusus untuk memberikan penjelasan / Syarah kitab Bukhari yang sudah masyhur di kalangan umat muslim adalah kitab Fathul Baari (kemenangan sang Pencipta) yang ditulis oleh Ibnu Hajar. Beliau adalah seorang ahli hadits yang Iahir di Mesir.

Menurut muridnya, imam asySyakhawi, karya beliau mencapai lebih dari 270 kitab. Kebanyakan berkaitan dengan pembahasan hadits, secara riwayat dan dirayat. Diantara karya beliau yang paling terkenal adalah kitab Fathul Baari, yaitu kitab yang menjelaskan haditshadits yang diriwayatkan oleh imam Bukhari dalam kitab shahihnya. Penulisan kitab ini menghabiskan waktu seperempat abad (817 H - 842 H) sehingga tidak mengherankan bila kitab ini paling bagus, teliti dan sempurna diantara syarah-syarah hadits Bukhari lainnya.

Atas dasar itulah kita perlu mengetahui lebih dalam lagi tentang bagaimana pendapat beliau dalam memahami hadits-hadits yang diriwayatkan oleh imam Bukhari dalam kitab shahihnya yang dalam kitab Fathul Baari, sehingga nantinya akan tercipta sebuah konsep yang jelas tentang konsep pendidikan Islam. Jika selama ini ahli hadits hanya mengintepretasikan opininya dalam bingkai religiusitas, maka ternyata setelah dielaborasi lebih mendalam, terdapat nila-nilai Pendidikan Islam yang mereka utarakan, jelas ini merupakan tambahan pemikiran terkait khazanah wawasan konsep pendidikan islam.

\section{Metode}

Pembahasan ini tergolong penelitian pustaka (library research) karena semua yang digali adalah bersumber dari pustaka. Oleh karena itu, guna mendapatkan data-data yang dibutuhkan, penulis menelaah buku-buku kepustakaan yang relevan dengan pembahasan ini. Adapun sumber data primer yang digunakan pada penulisan ini adalah kitab yang berjudul Fathul Baari, yang ditulis oleh Ibnu Hajar. Dalam analisis data kualitatif, metode yang digunakan untuk membahas sekaligus sebagai kerangka berpikir pada penulisan ini adalah metode analisis konten, yaitu suatu usaha untuk mengumpulkan dan menyusun data. Kemudian diusahakan pula dengan analisa dan interpretasi atau 
Konsep Pendidikan Islam dalam Kita6 Fathul Barri ...

Oleh: Minggusta Juliadarma

penafsiran terhadap data-data tersebut.

Setelah data terkumpul, kemudian dianalisa dengan menggunakan metode deskriptif analisis. Metode analisis yaitu jalan yang ditempuh untuk mendapatkan ilmu pengetahuan ilmiah dengan mengadakan perincian terhadap objek yang diteliti atau cara penanganan terhadap suatu objek ilmiah tertentu dangan jalan memilah-milah antara pengertian yang satu dengan pengertian yang lain guna sekedar memperoleh kejelasan mengenai suatu hal. Setelah itu, perlu dilakukan telaah lebih Ianjut guna mengkaji secara sistematis dan objektif.

\section{Pembahasan}

Untuk lebih memudahkan dalam memahami konsep pendidikan Islam dalam kitab Fathul Baari ini, penulis membuat sistematika sederhana yang merangkum segala hal yang dibutuhkan dalam penulisan ini.

\section{Definisi Pendidikan}

Dalam kitab Fathul Baari ada dua istilah yang digunakan oleh Ibnu Hajar dalam memaknai pendidikan, yaitu tarbiyah dan ta'dib. Ibnu Hajar mengartikan istilah tarbiyah dengan ilmu, kemudian dengan ilmu itu seseorang dapat mengajarkan ilmunya tersebut (Ibnu Hajar, 2003 : 288). Adapun istilah $t a^{\prime} d i b$ dalam kitab ini tidak ditemukan definisi secara khusus, tetapi dapat disimpulkan dari pemaparan Ibnu Hajar mengenai penggunaan istilah ta'dib selalu berkaitan dengan pembinaan adab dan akhlak.

Ibnu Hajar secara khusus tidak membedakan antara istilah tarbiyah dan $t a^{\prime} d i b$. Keduanya sering dipakai dalam memaknai segala kegiatan yang berkaitan dengan aktivitas mendidik dan pengembangan ilmu. Meski begitu karena 2 istilah tersebut berbeda dari segi makna, maka perlu kiranya kita cari perbedaan mendasar dari 2 istilah tersebut, seperti yang telah diungkap oleh Muhammad Naguib al-Attas yang menyatakan bahwa istilah ta'dib berisi ilmu dan amal, sedangkan istilah tarbiyah merupakan definisi umum dari bahasa inggris, yaitu education.

\section{Kedudukan IImu Dalam Pendidikan Islam}

Ibnu hajar menjelaskan bahwa Imam Bukhari sengaja tidak mencantumkan definisi ilmu secara spesifik dalam kitab shahihnya karena beliau menganggap bahwa hakikat ilmu telah diketahui oleh banyak orang. Imam Bukhari tidak mengarang kitabnya untuk menentukan definisi sesuatu, akan 


\section{Konsep Pendidikan Islam dalam Kita6 Fathul Barri...}

Oleh: Minggusta Juliadarma

tetapi kitab ini berlandaskan gaya Arab klasik yang memulai tulisan dengan menyebutkan keutamaan sesuatu untuk menarik perhatian jika hakikatnya telah diketahui.

Oleh karena itu dalam kitab Fathul Baari ini, Ibnu Hajar juga tidak menjelaskan tentang definisi ilmu. Meski begitu beliau mencantumkan pendapat Ibnu Arabi dalam kitab Syarah At-Tirmidzi yang membantah siapapun yang berusaha untuk mendefinisikan ilmu dan berkata, "Ilmu lebih jelas daripada upaya untuk menjelaskannya." Ibnu Hajar juga menjelaskan bahwa ini adalah metode Al Ghazali dan gurunya yang berpendapat bahwa ilmu tidak dapat didefinisikan karena kesukarannya atau kejelasannya sehingga tidak membutuhkan penjelasan lagi.

Menurut penulis, Ibnu Hajar tidak mencantumkan definisi ilmu secara khusus bukan berarti menolak penyebaran ilmu dan tergolong sebagai orang yang dimaksud dalam hadits nabi sebagai orang yang menyembunyikan ilmu, Islam menganjurkan penyebarluasan ilmu pengetahuan dan melarang menyembunyikan ilmu. Ibnu Hajar bertindak demikian karena pemahaman beliau yang luas akan definisi ilmu, tetapi definisi ilmu itu tidak tertuang dalam bentuk susunan kalimat secara khusus, tetapi berupa kandungan-kandungan ilmu yang mendalam yang terlihat pada pemaparan-pemaparan Ibnu Hajar dalam kitab ini, dalam arti lain Ibnu Hajar ingin mengedepankan definisi ilmu pada aspek praktisnya daripada aspek teoritisnya.

Ibnu Hajar juga menerangkan tentang konsepsi akal, bahwa tidak ada peranan akal manusia untuk menilai baik atau jelek terhadap sesuatu, karena hal tersebut dikembalikan kepada hukum syar'i. Segala sesuatu yang dianggap baik oleh syara', maka ia akan menjadi baik, dan apa yang dianggap buruk oleh syara', maka buruklah ia. Hanya kepada Allah dikembalikan segala rahasia yang terjadi di alam semesta ini, maka jika Allah membeberkan salah satu dari rahasia tersebut, maka akal tidak mungkin untuk dapat menggapainya. Karena sesungguhnya kemampuan akal manusia untuk mengetahui rahasia ketuhanan sangat terbatas, maka tidak seharusnya akal mempertanyakan mengapa dan bagaimana pengaturan-Nya, sebagaimana tidak pantas bagi akal untuk mempertanyakan darimana dan bagaimana wujud-Nya. ${ }^{1}$

$$
\text { Konsepsi akal yang }
$$
dipaparkan oleh Ibnu Hajar tersebut

1 Ibnu Hajar. (1984). Fathul Baari. Beirut: Daarul Kutub Ilmiyah. HIm. 313 
berkaitan dengan konsepsi akal yang berkaitan dengan hukum-hukum syar'i yang bersifat qath'i, sehingga pada wilayah ini kedudukan akal manusia akan sulit untuk memaksimalkan fungsinya karena tidak akan dapat menjangkaunya. Pemikiran Ibnu Hajar ini tidak membahas konsepsi akal secara menyeluruh dan teoretis seperti yang telah dipaparkan oleh para ahli pendidikan yang diteliti secara ilmiah tentang keberadaan dan fungsi akal pada manusia, tetapi lebih pada penanaman nilai-nilai religius dan ketuhanan.

Ibnu Hajar menerangkan bahwa mempelajari pengetahuan yang berhubungan dengan syari'at adalah langkah awal sebelum mempelajari pengetahuanpengetahuan lain di dunia ini, hal itu tersirat ketika beliau menjelaskan bahwa orang yang tidak mendalami agama atau tidak mempelajari dasardasar dan masalah-masalah furu'iyah dalam Islam, maka ia tidak akan mendapat kebaikan. Adapun fungsi dari mempelajari ilmu syari'at yaitu untuk menjelaskan apa-apa yang wajib bagi seorang mukallaf tentang urusan agama yang meliputi ibadah, muamalah, ilmu tentang Allah dan sifat-sifat-Nya.
Inilah sebenarnya perbedaan mendasar antara konsep pendidikan Islam dengan konsep pendidikan barat, yaitu terletak pada obyek kajian awal yang dibutuhkan anak untuk dapat berkembang sekaligus memandu kepribadian anak tersebut sehingga pada akhirnya akan bermuara pada satu tujuan, yaitu terbentuknya pribadi muslim yang bertakwa dan memilliki kepribadian yang baik. Berbeda sekali dengan pendidikan barat yang tidak menyentuh aspek-aspek religius pada masa awal perkembangan anak.

\section{Hubungan antara pendidikan dan kekuasaan}

Ibnu Hajar juga menyinggung adanya keterkaitan antara kekuasaan dengan pendidikan. Kekuasaan adalah hasil yang dicapai dari menuntut ilmu. Oleh karena itu para penuntut ilmu dianjurkan menggunakan waktunya dengan baik dalam mencari ilmu sebelum menjadi pemimpin. Hal ini sangat mendorong seseorang dalam menuntut ilmu, karena jika seseorang mengetahui bahwa ilmu merupakan perantara untuk mencapai kekuasaan, maka ia akan menjadi lebih giat belajar. ${ }^{2}$

Menurut penulis, pendapat Ibnu Hajar mengenai adanya keterkaitan kekuasaan dengan

2 Ibnu Hajar. (1984). Fathul Baari. Beirut: Daarul Kutub Ilmiyah. Hlm. 289 
pendidikan ini perlu penjelasan lebih mendalam lagi agar umat tidak terjebak pada titik kesimpulan yang salah, padahal pendapat Ibnu Hajar ini memiliki hikmah yang baik. Menurut Ibnu Hajar, kekuasaan adalah buah dari menuntut ilmu, tetapi tidak berarti maknanya menuntut ilmu untuk mencapai kekuasaan, karena hal itu merupakan dua hal berbeda dengan tujuan yang berbeda pula.

Maksud Ibnu Hajar di sini adalah bagaimana seorang muslim melakukan proses ikhtiyari dalam menemukan jalan hidup dan kualitas dirinya dengan cara menuntut ilmu. Sehingga apabila dia memiliki kualitas pada suatu pengetahuan, berarti dia telah mencapai derajat 'alim, seseorang yang memiliki ilmu akan memiliki pandangan luas dan karakteristik yang kuat, sehingga dengan bekal kualitas diri berkat tempaan selama menuntut ilmu itulah yang mengantarkan dirinya pada amanah untuk mengemban sebagai seorang pemimpin, sedangkan pemimpin itu tidak akan terlepas dari kekuasaan.

\section{Pendidik dan Tugasnya}

Dalam kitab Fathul Baari istilah yang digunakan untuk memaknai seorang pendidik adalah 'alim dan ulama'. Namun pengertian ulama' sebagai pendidik dalam hal ini dipersempit cakupannya dengan seseorang yang mengajarkan pengetahuan Islam. Mengenai pengkhususan ini Ibnu Hajar tidak menjelaskan lebih lanjut bahwa hal itu tidak termasuk ilmu-ilmu lainnya selain ilmu agama. Selain ulama', Ibnu Hajar juga menjelaskan bahwa kepala keluarga (ayah) juga memiliki tugas untuk mendidik keluarganya berupa memberikan nasehat kepada keluarganya.

Berikut ini penulis mencoba untuk mengeksplorasi segala hal yang berkaitan dengan tugas seorang pendidik dalam mengajarkan ilmunya dalam kitab Fathul Baari, diantaranya:

a. Mengulangi Penjelasan

Merupakan kebiasaan Rasulullah mengulangi penjelasan yang disampaikan, dalam beberapa hadits dijelaskan Rasulullah mengulangi sampai tiga kali. Tujuan Nabi mengulang perkataannya adalah agar mudah dipahami dan memberi peringatan terhadap orang yang enggan mengulangi pembicaraan dan mengingkari bahwa orang yang meminta pengulangan termasuk orang yang bodoh, tetapi hal itu tergantung perbedaan masing-masing tabiat manusia, makanya tidak tercela bagi seorang pendengar yang belum bisa mengingat pada kali pertama untuk meminta pengulangan. Begitu juga 
Oleh: Minggusta Juliadarma

bagi pembicara, tidak mengapa tidak mengulangnya kembali, namun jika mengulanginya, berarti sebagai penekanan terhadap apa yang dikatakan pada pertama kali. ${ }^{3}$

b. Memperhatikan Aspek Waktu Dalam Pendidikan

Seorang pendidik hendaknya memilih waktu yang tepat untuk memberi nasehat dan mengajarkan ilmu agar orang yang mendengar (murid) tidak merasa bosan dan meninggalkan majlis. Meskipun kontinuitas sangat diharapkan, namun hal itu dapat dilakukan dengan beberapa cara, yaitu dilaksanakan setiap hari dengan syarat tidak membebani, atau dilakukan dua hari sekali sehingga dapat melakukan perbuatan tersebut pada hari berikutnya dengan penuh semangat, atau bisa juga dilakukan seminggu sekali disesuaikan dengan kondisi masing-masing individu. ${ }^{4}$

Pemikiran Ibnu Hajar tersebut sangat relevan dengan apa yang terjadi saat ini sekaligus menjadi masukan bagi para pendidik, banyak sekali pendidik yang tidak memperhatikan aspek waktu dalam memberikan materi pada siswanya, hal itu karena tuntutan kurikulum dengan membatasi alokasi waktu dengan tidak memperhatikan kondisi masing-masing individu siswanya. Guru mengejar waktu untuk menyelesaikan materi pada waktu yang telah ditetapkan, akibatnya siswa kurang bisa menyerap materi yang sedang diajarkan, berbicara dan bergurau dengan temannya, mengantuk, dsb.

c. Merangkul dan Memeluk Anak

Ibnu Hajar menjelaskan hal ini terkait hadits yang menyebutkan Rasulullah merangkul Ibnu Abbas dan mendoakannya. Hal ini menunjukkan diperbolehkan merangkul dan mendoakan anak kecil sebagai ungkapan rasa kasih sayang (Ibnu Hajar, 2003 : 291). Dalam hadits lain Rasulullah mengusap kepala dan mendoakannya, Rasulullah melakukan hal itu karena beliau mengetahui kondisi Ibnu Abbas yang menguasai ilmu tafsir dan mempunyai pemahaman mendalam tentang agama.

Semua ini terkait pada pentingnya pendidik memperhatikan hal tersebut untuk membangun ikatan psikologis dengan anak sehingga nantinya lebih mudah pendidik dalam mendidik anak tersebut.

d. Membangunkan Anak Untuk Shalat Lail

Hal ini terkait hadits yang menyebutkan bahwa Rasulullah

3 Ibnu Hajar. (1984). Fathul Baari. Beirut: Daarul Kutub Ilmiyah. Hlm. 299

4 Ibid. hlm. 288 


\section{Konsep Pendidikan Islam dalam Kita6 Fathul Barri...}

Oleh: Minggusta Juliadarma

membangunkan Ibnu Abbas untuk melaksanakan shalat lail. ${ }^{5}$ Membiasakan anak untuk bangun di malam hari untuk beribadah pada Allah adalah sesuatu yang perlu diperhatikan bagi para pendidik untuk membiasakan anak beribadah di malam hari karena manfaat dan keutamaannya yang tinggi. Dan ini juga karakteristik pendidikan Islam dibandingkan pendidikan barat yang cenderung sekuler.

e. Marah Dalam Memberi Nasihat dan Mengajar

Diperbolehkan bagi pendidik untuk marah dalam memberi nasihat dan mengajar jika melihat sesuatu yang dibenci. Sesuatu yang dibenci ini misalnya ada dalam hadits, ketika seseorang bertanya sesuatu pada Nabi sehingga menimbulkan kemarahannya, kemudian Ibnu Hajar menjelaskan kemarahan Nabi itu karena apa yang ditanyakan tersebut sudah pernah dilarang sebelumnya, atau si penanya kurang begitu paham. ${ }^{6}$

Ibnu Hajar membatasi bentuk kemarahan tersebut hanya sebatas untuk memberi nasihat dan pendidikan, tidak dalam aspek hukum, karena seorang pemegang otoritas hukum tidak diperkenankan memutuskan sesuatu ketika dia sedang marah. Perbedaannya, bahwa orang yang memberi nasihat boleh menampakkan sikap marah, karena dia sebagai orang yang memberi peringatan. Begitu juga seorang guru, jika dia mencela kesalahan murid yang belajar kepadanya, karena terkadang hal itu terpaksa dia Jakukan agar si murid dapat menerima kebenaran darinya, akan tetapi hal itu harus disesuaikan dengan kedaan psikologi masingmasing murid. ${ }^{7}$

Ibnu hajar menghubungkan sikap marah seorang pendidik dengan marahnya hakim karena beliau sangat kompeten sekali di bidang hukum, oleh karenanya beliau pernah menjadi Oadhi (hakim) di Mesir selama dua puluh tahun.

f. Meninggikan Suara

Diperbolehkan meninggikan suara untuk memberi tahu, karena jaraknya yang terlalu jauh dan banyaknya orang yang hadir dalam majlis. ${ }^{8}$

g. Memperingati Murid Pada Sesuatu yang Ingin Dicapai

Seorang pendidik harus memberi peringatan kepada muridnya dari segala sesuatu yang ingin dicapai dan memberi pengarahan untuk menghadapi sesuatu yang diwaspadai. ${ }^{9}$
5 Ibid. hlm. 309

6 Ibid. hlm. 298

7 Ibid. hlm. 299
8 Ibid. hlm. 280

9 Ibid. hlm. 309 
Oleh: Minggusta Juliadarma

h. Tidak Mengindahkan Pertanyaan yang Lain Ketika Pendidik Sedang Menjawab Pertanyaan

Sebuah peringatan bagi pendidik agar tidak mengindahkan pertanyaan orang yang bertanya di saat ia sedang berbicara, namun hendaknya ia menyempurnakan terlebih dahutu jawabannya dan baru setelah itu menjawab apa yang ditanyakan pada pertanyaan berikutnya dengan nada yang lemah lembut. Ibnu Hajar juga menyinggung hal-hal yang berkaitan dengan pembahasan ini dengan diperbolehkannya menjawab pertanyaan meski pertanyaan tersebut tidak fokus pada pembahasan yang sedang dikaji. ${ }^{10}$

i. Memberitakan Keadaan Orang Bermaksiat (melakukan kejelekan) Dengan Maksud Untuk Mencela Perbuatan Tersebut

Ibnu Hajar menerangkan hal tersebut dalam menjelaskan hadits tentang keadaan tiga orang yang datang, dua orang diantaranya masuk ke dalam masjid dan satu orang lagi pergi meninggalkan masjid. Lalu Rasul memberitakan keadaan masing-masing orang tersebut sementara orang yang dimaksud tersebut masih ada dalam majlis. Ibnu Hajar juga menerangkan bahwa hal tersebut tidak dianggap ghibah. ${ }^{11}$
Dapat kita pahami dari penjelasan Ibnu Hajar dalam memaknai hadits tersebut bahwa seorang guru diperbolehkan untuk menegur dan menasehati anak di dalam forum (kelas) dengan tujuan untuk mencela perbuatan jelek yang dilakukan oleh anak yang telah melakukan tersebut agar temantemannya yang lain dapat mengambil ibrah (pelajaran/manfaat) dan menghindari perbuatan jeleknya. Namun apabila penulis bandingkan dengan ahli psikologi anak, maka akan terjadi perbedaan, karena ketika guru menegur anak di depan teman-temannya akan berdampak buruk pada mentalnya.

Menurut penulis kedua pendapat ini sebenarnya dapat digabungkan menjadi formula yang tepat untuk mengatasi perbuatan jelek yang dilakukan anak. Teguran guru itu harus dilakukan dengan cara yang lemah lembut tanpa ada beban menghakimi dan memvonis bersalah pada anak tersebut, tetapi pendidik juga harus menjelaskan letak kesalahan murid itu di depan temannya agar mereka juga tahu bahwa perbuatan yang dilakukan temannya itu adalah perbuatan yang harus dihindari.

\section{Penuntut Ilmu}

10 Ibid. hlm 279
11 Ibid. hlm. 286

el Bidayah: Journal of Islamic Elementary Education Volume 1, Nomor 1, Maret 2019 


\section{Konsep Pendidikan Islam dalam Kita6 Fathul Barri...}

Oleh: Minggusta Juliadarma

Ibnu Hajar memberikan istilah untuk orang yang menuntut ilmu dengan sebutan muta'allim. Beliau juga menuliskan contoh perjuangan penuntut ilmu untuk mendapatkan petunjuk dari seseorang yang dianggap lebih pintar darinya, yaitu kisah perjuangan Nabi Musa 'alaihi salam untuk belajar kepada Nabi Khidhir 'alaihi salam. Nabi Musa meski telah mendapatkan kedudukan dan diberi ilmu yang tinggi, tetapi hal itu tidak menghalanginya untuk menuntut ilmu, bahkan beliau mengarungi lautan dan daratan hanya untuk belajar. Dari sini jelaslah korelasi antara penuntut ilmu dengan kisah Nabi Musa dan Nabi Khidhir ini. Hanya saja, yang menjadi kekurangsempurnaan dari penjelasan Ibnu Hajar di atas adalah tidak diceritakan bagaimana kisah proses nabi Musa menuntut ilmu pada nabi Kbidhir secara lengkap. ${ }^{12}$

Banyak perbedaan pendapat di kalangan ulama mengenai usia tamyiz, yaitu usia dimana anak dapat membedakan mana yang benar dan mana yang salah. Ada yang berpendapat anak yang berumur lima tahun sudah dapat dikategorikan sebagai anak yang telah mampu untuk mendengarkan dan memperhatikkan pelajaran dalam suatu majlis, sedangkan anak yang di bawah lima tahun hanya dikatakan hadir dalam majlis itu dan tidak dapat dikatakan mendengar. Ulama fikih menyatakan bahwa usia tamyiz adalah usia 6 atau 7 tahun. ${ }^{13}$

Menurut imam Bukhari yang menjadi pijakan dalam hal ini adalah pemahaman. Oleh karena itu barangsiapa yang memahami objek pembicaraan berarti dia telah mumayyiz, meskipun dia anak yang berumur di bawah lima tahun, tetapi jika dia belum memahaminya, maka kita tidak dapat mengatakan bahwa dia telah mumayyiz. Lalu Ibnu Hajar memberikan pendapatnya mengenai hal tersebut dengan mengatakan bahwa pendapat yang paling kuat adalah pendapat yang menyatakan bahwa yang dimaksud dalam hal ini adalah pemahaman.

Jika usia tamyiz yang ada dalam kitab ini penulis bandingkan dengan ahli psikologi, maka akan terjadi perbedaan yang sangat mencolok, Dalam buku Psikologi Perkembangan tentang periodesasi perkembangan menurut konsep Islam, disebutkan bahwa usia mumayyiz atau tamyiz adalah sekitar 7 sampai 12 tahun. Satu fase di atas fase al thifl dan dibawah fase baligh. ${ }^{14}$
12 Ibid. hlm. 290

13 Ibid. hlm. 293
14 Desmita. (2009). Psikologi Perkembangan Peserta Didik. Bandung: Remaja Rosdakarya. HIm. 25-26 
Oleh: Minggusta Juliadarma

Pendapat di atas dikuatkan oleh Said Hawwa dalam Al Islam nya yang mengatakan bahwa usia baligh untuk laki-laki itu kalau ia sudah mimpi atau sekitar umur 15 tahun sementara untuk perempuan ditandai dengan haid. Penulis menangkap kalau usia baligh itu sekitar 15 tahun, berarti usia tamyiz itu ada dibawah 15 tahun, sementara usia 12 tahun termasuk di dalamnya.

Kemudian Ibnu Hajar membahas mengenai adanya perbedaan antara lafadz Al-Inshat dan Al-Istima'. kata tersebut memiliki arti yang berbeda, karena kata inshat berarti diam yang dapat dilakukan oleh orang yang mendengar dan tidak mendengar. Adapun kata istima' dapat dilakukan dengan diam atau berkata-kata yang tidak menyibukkan si pembicara untuk memahami apa yang didengarnya. ${ }^{15}$

Baik istima' maupun inshat, penulis melihat ada persamaan antara keduanya, yaitu sama-sama merupakan salah satu cara agar murid dapat memahami guru yang sedang menjelaskan dan salah satu adab yang penting untuk diperhatikan oleh para murid ketika guru sedang menjelaskan materi.

Ibnu Hajar mengkorelasikan antara sifat hasad dan ghibthah dengan pendidikan yaitu persaingan untuk berlomba-lomba dalam menuntut ilmu. Hasad adalah sifat yang terdapat dalam diri seseorang, sehingga ia menginginkan hilangnya nikmat yang dimiliki orang lain. Sebagian orang berpendapat bahwa hasad adalah menginginkan hilangnya nikmat dari orang lain untuk menjadi miliknya sendiri. Akan tetapi pendapat yang benar adalah yang mengatakan bahwa hasad adalah bersifat umum. Hal ini disebabkan karena manusia memiliki tabiat selalu ingin mengungguli orang lain sehingga apabila ia melihat orang lain memiliki sesuatu yang tidak dimilikinya, maka ia akan berharap agar benda itu lepas dari tangannya, dengan demikian ia akan lebih unggul atau paling tidak, dapat menyamainya.

Orang yang memiliki sifat semacam ini adalah orang yang tercela, jika hal itu terbetik dalam hati atau diungkapkan dengan perkataan dan perbuatannya. Oleh karena itu, sifat tersebut harus dijauhi sebagaimana laranganlarangan lainnya. Sifat hasad diperbolehkan jika nikmat tersebut dimiliki oleh orang kafir atau fasik yang dijadikan sebagai sarana untuk berbuat maksiat kepada Allah. Ini adalah definisi hasad secara umum

15 Ibnu Hajar. (1984). Fathul Baari. Beirut: Daarul Kutub Ilmiyah. Hlm. 312 


\section{Konsep Pendidikan Islam dalam Kita6 Fathul Barri...}

Oleh: Minggusta Juliadarma

seperti yang telah penulis sampaikan sebelumnya.

Sedangkan ghibthah adalah seseorang berharap mendapatkan nikmat yang ada pada seseorang tanpa menginginkan hilangnya nikmat dari orang tersebut. Hal semacam ini juga disebut dengan persaingan yang jika dilakukan untuk ketaatan, maka termasuk perbuatan yang mulia. ${ }^{16}$

Setelah mencermati hal di atas, penulis dapat menyimpulkan bahwa Ibnu Hajar ingin memperingatkan pada penuntut ilmu untuk menjauhi sifat hasad dalam menuntut ilmu dan mendorong mereka untuk lebih mengedepankan sifat ghibthah daripada hasad, karena berlombalomba dalam kebaikan dan menuntut ilmu merupakan perintah dari Allah yang telah tersebut dalam al-Qur'an dan hadits.

Kalau kita tinjau dari segi bahasa, kedua lafadz tersebut memiliki arti sama, yaitu iri. Penulis menilai, Ibnu Hajar mengingkari lafadz hasad karena lafadz itu sudah umum dikategorikan sebagai salah satu akhlak tercela, sehingga tidak dapat digunakan untuk memaknai suatu perbuatan mulia, yaitu menuntut ilmu.

Berikut adalah segala hal yang berkaitan dengan apa yang seharusnya diperhatikan oleh para penuntut ilmu dalam menuntut ilmu, diantaranya:

a. Belajar Pada Orang yang Lebih Mampu.

Seorang penuntut ilmu hendaknya mengambil ilmu atau belajar kepada orang yang lebih mampu dan menanyakan sesuatu yang belum dipahami kepada orang yang lebih mengetahui sehingga menjadi jelas apa yang belum dipahami. Faedah yang dapat kita petik dari sini adalah seharusnya penuntut ilmu belajar pada guru yang benar-benar menguasai ilmu yang akan diajarkannya sehingga si murid dapat mengambil banyak manfaat darinya, hal ini juga sesuai dengan hadits tentang larangan bertanya pada orang yang tidak mengetahui.

b. Duduk yang Terdepan

Ibnu Hajar menjelaskan pemahaman beliau tentang hal ini, yaitu orang yang datang lebih dahulu berhak untuk duduk di depan dalam suatu majlis. Demikian pula dianjurkan untuk mengisi tempat yang kosong dalam majlis tersebut sebagaimana anjuran untuk mengisi shaf yang kosong dalam shalat. Tetapi bedanya dalam hal ini, seseorang diperbolehkan untuk lewat di depan orang lain selama tidak mengganggunya. Jika merasa hal itu dapat mengganggu, maka 
dianjurkan untuk duduk paling belakang.

Pada masa Rasul, majlis ilmu berbentuk melingkar (halaqah), tetapi penjelasan Ibnu Hajar di atas juga berlaku untuk majlis ilmu yang menggunakan bentuk selain halaqah, seperti sistem kelas dengan satu bangku dan dua kursi tertata rapi memenuhi ruangan atau sistem di perguruan tinggi dengan satu kursi yang dilengkapi dengan alas untuk menulis yang tertata rapi memenuhi ruangan, bentuk seperti itu yang lazim digunakan pada era pendidikan saat ini.

c. Adab Menanyakan Sesuatu Pada Guru

Adab yang harus diperhatikan oleh penuntut ilmu dalam bertanya pada guru adalah pertanyaan yang tidak bermanfaat atau sengaja bertanya dengan niat untuk menyakiti guru atau orang yang akan menjawab merupakan sesuatu yang harus dihindari.

Demikian pula bagi yang memberi pertanyaan hendaknya tidak terlalu umum, supaya tidak membingungkan bagi yang akan menjawab, ${ }^{17}$ meskipun adab bagi guru pula menjawab pertanyaan murid yang pertanyaannya tidak terfokus pada permasalahan yang sedang dibahas, 18 hal itu untuk membantu rasa ingin tahu murid terhadap suatu permasalahan yang masih membingungkan baginya.

Adab yang lain tentang perihal ini adalah larangan bertanya dengan niat membangkang dan mencurigakan. Hal itu dapat membuat marah seseorang yang ditanya. ${ }^{19}$ Ibnu Hajar juga menganjurkan pada para penuntut ilmu untuk menanyakan sesuatu yang terlewat karena ketidakhadirannya pada saat itu dan menanyakan sesuatu yang didengar sampai mengerti.

\section{d. Mencari Nafkah}

Di samping menuntut ilmu, juga dianjurkan untuk mencari nafkah (penghasilan) agar dapat digunakan untuk kebutuhan belajarnya. ${ }^{20}$ Inilah nilai-nilai tinggi dalam pendidikan Islam yang mengharuskan suatu perbuatan mulia, yaitu menuntut ilmu harus diikuti dengan cara yang mulia pula di dalam mendapatkannya (ilmu), yaitu dengan jalan mencari nafkah. Banyak sekali para sahabat yang mencari nafkah meskipun dia sedang menuntut ilmu pada Rasulullah, seperti Amru bin Ash, Utsman bin Affan, Abu Bakar dan banyak yang lain dengan berdagang.
17 Ibid. hlm. 281

18 Ibid. hlm. 279
${ }^{19}$ Ibid. hlm. 281

20 Ibid. hlm. 298

el Bidayah: Journal of Islamic Elementary Education Volume 1, Nomor 1, Maret 2019 


\section{Konsep Pendidikan Islam dalam Kita6 Fathul Barri... \\ Oleh: Minggusta Juliadarma}

Hal ini mungkin yang luput dari penuntut ilmu saat ini, kebanyakan dari mereka lebih mengandalkan nafkah dari orang tua mereka sehingga mereka hanyut dalam kemanjaan diri. Berbeda dengan seseorang yang menuntut ilmu dari hasil mencari nafkah, mereka akan lebih giat dalam belajarnya karena mereka sadar bahwa jalan untuk. mendapatkannya (ilmu) sangat sulit dan itu akan lebih memotivasi mereka.

e. Alkohol Dapat Merusak Akal

Ibnu Hajar menyebutkan bahwasanya meminum alkohol akan merusak pikiran adalah salah satu dari 5 tanda yang menjadi pemicu kesenjangan dan kerusakan. Inilah yang harus dihindari oleh murid dalam menuntut ilmu. ${ }^{21}$

\section{f. Adab Yaumiyah}

Ibnu Hajar menerangkan bahwa ketika seseorang dalam keadaan terkejut dianjurkan untuk mengucapkan subhanallah. Demikian pula ketika seseorang bangun dari tidurnya, dianjurkan untuk menyebut nama Allah. Bertasbih merupakan cara untuk lepas dari halhal yang menakutkan ketika kita melihatnya. ${ }^{22}$

Semua itu merupakan kebiasaan-kebiasaan mulia dalam pendidikan Islam yang sangat dianjurkan untuk dilakukan ketika penuntut ilmu mengalami kejadiankejadian yang telah disebut di atas.

\section{g. Dilarang Bersikap Malu Dalam Menuntut Ilmu}

Sikap ini sangat dianjurkan dalam syari'at jika dilakukan untuk menghormati orang-orang yang lebih tua. Adapun malu yang dapat melalaikan perintah-perintah syari'at adalah malu yang tercela dan bukanlah malu yang disyariatkan. Itulah yang dimaksud oleh Mujahid dengan ungkapannya,"Tidaklah menuntut ilmu orang yang malu". Seolah-olah yang dia maksudkan adalah anjuran kepada orang-orang yang menuntut ilmu agar mereka melepas sikap ketidakberdayaan dan sombong, yang keduanya bisa mempengaruhi ketidaksempurnaan dalam menuntut ilmu. ${ }^{23}$

\section{h. Diperbolehkan Berdebat Dalam Menuntut Ilmu.}

Ibnu Hajar menerangkan hal tersebut di atas diperbolehkan dengan memberikan contoh kisah nabi Musa yang berdebat dengan nabi Khidir tentang permasalahan yang berkaitan dengan pengetahuan. ${ }^{24}$

\section{Metode Pendidikan}

\footnotetext{
${ }^{23}$ Ibid. hlm. 316

${ }^{24}$ Ibid. hlm. 291
}

21 Ibid. hlm. 295

22 Ibid. hlm. 309 
Apa yang ingin disampaikan guru tidak akan tersalurkan dengan optimal jika tidak menggunakan metode pendidikan yang sesuai. Untuk itu guru harus memahami dan mencari metode-metode apa yang sesuai untuk digunakan dalam menyampaikan materi pelajaran yang akan disampaikan. Ketidak tepatan dalam penerapan metode ini akan menghambat proses belajar mengajar yang akan berakibat membuang waktu dan tenaga yang tidak perlu. ${ }^{25}$

Dalam kitab Fathul Baari ini ada beberapa metode pendidikan yang dapat diterapkan oleh guru meskipun tidak dijelaskan secara terperinci oleh Ibnu Hajar langkahlangkah operasionalnya, diantaranya sebagai berikut:

a. Dialog dan Diskusi

Rasul tidak pernah merasa bosan untuk menjelaskan setiap pertanyan yang datang kepadanya, begitu pula ketika Rasul menjawab pertanyaan- pertanyaan yang ditanyakan oleh Aisyah untuk memahami makna setiap hadits, oleh karena itu Ibnu Hajar mengambil pelajaran dari riwayat ini bahwa mengadakan dialog dan mendiskusikan sesuatu diperbolehkan.

25 Ibid. hlm. 197

26 Ibid. hlm. 279
Termasuk kategori diskusi dan dialog adalah metode tanya jawab karena menurut Ibnu Hajar ilmu itu dapat diperoleh melalui tanya jawab. ${ }^{26}$ Metode ini juga berguna untuk menguji kemampuan murid dengan apa yang tersembunyi dan memberitahukannya jika mereka tidak mengetahui tentang sesuatu.
b. Metode
Bertahap
Dalam
Penyampaian

Menggunakan metode bertahap dalam mengajarkan suatu ilmu sangat baik, karena segala sesuatu jika diawali dengan kemudahan, maka akan dapat memikat hati dan menambah rasa cinta. Berbeda halnya jika pendidikan itu dimulai dengan kesulitan. ${ }^{27}$ Maksudnya adalah dalam menyampaikan suatu materi pada murid, hendaknya guru memperhatikan kondisi dan karakter murid yang berbeda - beda. Karena tidak semua murid dapat dengan mudah memahami apa yang disampaikan oleh guru dalam satu waktu sekaligus, hal itu membutuhkan waktu sehingga murid dapat lebih memahami apa yang disampaikan guru jika membiarkan mereka paham terlebih dahulu tentang sebagian penjelasan yang guru sampaikan, kemudian setelah itu guru melanjutkan pada pembahasan yang selanjutnya.
${ }^{27}$ Ibid. hlm. 288

el Bidayah: Journal of Islamic Elementary Education Volume 1, Nomor 1, Maret 2019 


\section{Konsep Pendidikan Islam dalam Kita6 Fathul Barri... \\ Oleh: Minggusta Juliadarma}

Metode tersebut sering Rasul gunakan dalam mendidik para sahabat dan memberitahu tentang suatu hukum perkara secara bertahap seperti hukum meminum khamr (minuman keras).

c. Metode Sama'i, 'Ard, Munawalah, Mukatabah

Sebagai ulama hadits, Ibnu Hajar juga menjelaskan beberapa metode yang biasa digunakan oleh seseorang yang ingin mempelajari ilmu badits atau seseorang yang ingin mendapatkan hadits dari gurunya, yaitu metode sama'i (mendengar) dan 'ard. Metode 'ard adalah apa yang dikemukakan oleh seorang murid kepada gurunya atau kepada orang lain dengan kehadiran gurunya. ${ }^{28}$ Sebagian orang memperluas pengertian 'ard, yaitu jika seseorang menghadirkan gurunya dan melihatnya serta ia mengetahui kebenarannya, lalu ia mengizinkan untuk meriwayatkan darinya.

Metode lainnya adalah metode mukatabah, yaitu seorang guru menulis hadits dengan tulisannya sendiri, atau ia mengizinkan orang lain yang dipercaya untuk menulis hadits tersebut. Kemudian setelah selesai, ia mengirimnya kepada si murid dan mengizinkannya untuk meriwayatkan hadits tersebut. ${ }^{29}$
Metode yang hampir mirip dengan metode mukatabah adalah metode munawalah, yaitu seorang guru memberikan sebuah kitab kepada muridnya dan berkata,"Kitab ini adalah hasil pendengaranku dari si fulan, atau kitab ini untuk bisa memahami apa yang disampaikan oleh guru karena jaraknya yang terlalu jauh". Isyarat Tangan dan Kepala Rasulullah apabila menyampaikan perkataan pada para sahabat sering menggunakan gerakgerik. Begitu pula dengan pemberian isyarat dari Nabi dilakukan dengan gerakan tangan beliau. Seperti misalnya Nabi menggerakkan tangannya seperti gerakan orang yang hendak memukul. ${ }^{30}$

Kebodohan Menjadi Sebab Matinya Pendidikan Islam. Ibnu Hajar menerangkan adanya keterkaitan yang erat antara punahnya ilmu pengetahuan dan kematian ulama (seseorang yang mengajarkan ilmu) dengan timbulnya kebodohan. Sehingga itu juga akan berimplikasi pada matinya pendidikan Islam. Selama masih ada orang yang mempelajari ilmu, maka kepunahan ilmu tidak akan terjadi. ${ }^{31}$

Ilmu juga merupakan salah satu tanda datangnya kiamat. Allah SWT menarik kembali ilmu pengetahuan dan mencabutnya dari 
hati manusia dengan cara mematikan orang-orang yang berpengetahuan (ulama'). Apabila orang berpengetahuan telah tiada, maka masyarakat akan mengangkat orangorang bodoh menjadi pemimpin yang akan dijadikan tempat bertanya. Orang-orang bodoh ini akan berfatwa tanpa ilmu, mereka kemudian semakin menyesatkan umat, sehingga timbullah kebodohan dimana-mana. ${ }^{32}$

\section{Perbedaan Konsep Pendidikan Islam Dalam Kitab Fathul Baari Dengan Konsep Pendidikan Lain}

Dalam sub bab ini penulis mencoba untuk memetakan perbedaan- perbedaan yang ada antara konsep pendidikan yang penulis telah temukan dalam penulisan ini dengan konsep pendidikan Islam yang diusung oleh pakar pendidikan yang lain, dalam penelitian ini kami memilih Muhammad Naquib al-Attas, Abdurrahman an-Nahlawi dan alGhazali sebagai pembanding.

Penulis sengaja memilih ketiga tokoh tersebut karena, 1). Ruang lingkup materi pembahasan konsep yang mereka rumuskan, ada beberapa yang dapat ditemukan dalam kitab Fathul Baari, 2). Antara 3 tokoh tersebut memiliki perbedaan mendasar yang sangat mencolok tentang beberapa isu strategis pendidikan Islam, kemudian penulis ingin mengetahui pendapat Ibnu Hajar sendiri tentang beberapa perbedaan pandangan tersebut. Namun demikian, pemetaan perbedaan dalam penelitian ini, sengaja penulis tidak menganalisis secara mendetail, hal ini hanya sekedar untuk penyempumaan penulisan ini dengan model studi komparasi sederhana dan tidak memilih pendapat yang paling benar. Diantara perbedaan-perbedaan tersebut. Diantaranya sebagai berikut:

1. Ibnu Hajar memaknai pendidikan dengan istilah tarbiyah dan ta'dib dengan tidak membedakan kedua lafadz tersebut dalam menjelaskan hadits-hadits yang mengandung pendidikan. Hal berbeda dikemukakan oleh Muhammad Naguib Al-Attas yang menyatakan bahwa istilah tarbiyah tidak sesuai jika dijadikan sebagai istilah untuk pendidikan, yang lebih sesuai menurutnya adalah dengan mengistilahkan pendidikan dengan istilah ta'dib, karena dengan istilah itu telah terkumpul ilmu dan amal. ${ }^{33}$ Berbeda dengan 


\section{Konsep Pendidikan Islam dalam Kita6 Fathul Barri...}

Oleh: Minggusta Juliadarma

pandangan Ibnu Hajar dan Naquib Al- Attas, An-Nahlawy membedakan istilah tarbiyah dan ta'dib. Lafadz tarbiyah dimaksudkan sebagai proses pendidikan dan upaya pendidikan yang menembus pada aspek etika religius dan ta'dib sebagai pendidikan moral.

2. Ibnu Hajar menyebutkan klasifikasi ilmu syariat dengan ibadah, muamalah, ilmu tentang Allah dan sifat-sifatnya. Adapun Al-Ghazali membagi ilmu syariat dengan al-Ushul (pokok) yaitu mempelajari al-Quran dan sunnah nabi, Al-Furu' (cabang) yaitu ilmu fikih, Mukaddimah (pengantar) yaitu Nahwu, Sharaf dan Balaghah, Al-Mutammimah (pelengkap) yaitu ilmu tafsir. ${ }^{34}$

3. Ibnu Hajar membolehkan guru untuk marah kepada muridnya dalam memberikan nasehat. Bahkan jika dalam keadaan terpaksa, guru diperbolehkan mencela kesalahan murid, hal itu dilakukan agar dapat menerima kebenaran darinya, akan tetapi tindakan tersebut harus disesuaikan dengan kedaan psikologi masing-masing murid. Berbeda dengan Al-Ghazali yang menyatakan bahwa hendaknya

\footnotetext{
34 Fathiyah Hasan. (1990). Konsep Pendidikan Al-Ghazali. Jakarta: P3M. Hlm. 37

35 Muhammad Arifin. (2008). Ilmu Pendidikan Islam. Jakarta: Bumi Aksara. Hlm. 49 el Bidayah: Journal of Islamic Elementary Education Volume 1, Nomor 1, Maret 2019
}

guru menghindari sifat marah kepada muridnya karena hal itu akan membuat mereka berani dan menjauh, menolak dan takut pada gurunya, sebisa mungkin nasehat itu dengan cara sindiran tidak secara terang-terangan..$^{35}$

4. Ibnu Hajar juga menerangkan tentang konsepsi akal, bahwa tidak ada peranan akal manusia untuk menilai baik atau jelek terhadap sesuatu, karena hal tersebut dikembalikan kepada hukum syar'i. Adapun Naquib alAttas menerangkan akal merupakan suatu substansi ruhaniah yang dapat memahami dan membedakan kebenaran dan kepalsuan. ${ }^{36}$

5. Istilah rabbani dalam kitab Fathul Baari diidentikkan dengan ulama' dan fuqaha' berdasarkan informasi dari hadits yang diriwayatkan oleh Ibnu Abbas ra, tetapi Naquib al-Attas menandaskan bantahannya dengan menyebutkan pendapat dari Ibnu 'Ubaid yang menyatakan istilah rabbani pada hakikatnya bukan istilah bahasa Arab, melainkan istilah Ibrani, kemudian dia menjelaskan pengertian robbani, yaitu nama yang diberikan bagi orang-orang

\footnotetext{
36 Muhammad Naquib Al-Attas. (1984). Konsep Pendidikan Islam. Bandung: Mizan. hlm. 38
} 
bijaksana yang terpelajar dalam bidang pengetahuan tentang $a r$ rabb. ${ }^{37}$

\section{Kesimpulan}

Konsep Pendidikan Islam dalam kitab Fathul Baari dapat terlihat dari pemikiran-pemikiran Ibnu Hajar mengenai konsepsi akal manusia yang tidak akan pernah dapat menjangkau rahasia-rahasia Allah SWT, sekalipun akal itulah yang akan membawa manusia untuk dapat mempelajari ilmu syariah sebagai pengetahuan dasar yang harus dipelajari manusia sejak dini. Meski demikian, untuk menyempurnakan ilmu tersebut agar dapat memberikan manfaat, diperlukan adanya perkataan dan perbuatan, karena dua hal tersebut merupakan syarat agar ilmu dapat termanfaatkan, sehingga apa yang dipelajari oleh manusia akan lebih bermanfaat jika ilmu tersebutdapat diejawantahkan menjadi sebuah kepribadian yang baik.

Ibnu Hajar juga menjelaskan pemikirannya mengenai pendidik, tugas-tugasnya, dan metode pendidikan yang sesuai untuk diaplikasikan dalam menerangkan materi. Selain itu, Ibnu Hajar menerangkan pendapatnya mengenai penuntut ilmu dan adabadabnya dalam menuntut ilmu.

Ibnu Hajar mengemukakan pandangannya tentang adanya keterkaitan yang erat antara punahnya ilmu pengetahuan dan kematian ulama' dengan timbulnya kebodohan. Sehingga itu akan berimplikasi pada matinya pendidikan Islam.

Setelah penulis mengamati konsep pendidikan Islam yang terdapat dalam kitab Fathul Baari dengan konsep pendidikan Islam menurut pakar pendidikan Islam yang lain, penulis mendapati adanya beberapa perbedaan mendasar dari berbagai aspek, diantaranya perbedaan tentang istilah tarbiyah yang digunakan dalam memaknai pendidikan, klasifikasi ilmu-ilmu syariat sebagai pengetahuan dasar seseorang dalam menuntut ilmu, boleh tidaknya guru marah dalam menasehati muridnya, konsepsi akal dan perbedaan tentang definisi dari rabbani.

\section{Daftar Pustaka}


Al-Attas, Naquib. 1984. Konsep Pendidikan Islam. Bandung: Mizan.

Arifin, Muhammad. 2008. Ilmu Pendidikan Islam. Jakarta: Bumi Aksara.

Daradjat, Zakiah. 2000. Ilmu Pendidikan Islam. Jakarta: Bumi Aksara.

Desmita. (2009). Psikologi Perkembangan Peserta Didik. Bandung: Remaja Rosdakarya.

Fakultas Tarbiyah IAIN Walisongo. 2001. Paradigma Pendidikan Islam. Yogyakarta: Pustaka Pelajar.

Hajar, Ibnu. 2003. Fathul Baari. Beirut: Darul Kutub Ilmiyah.

Hasan, Fathiyah.1990. Konsep Pendidikan Al-Ghazali. Jakarta: P3M.

Putra, Ary Antony. 2017. "Konsep Pendidikan Agama Islam Perspektif Imam Al-Ghazali". AlThariqah: Jurnal Pendidikan Agama Islam, 1(1).

Saleh, Abdurrahman. 1990. Teoriteori Pendidikan Berdasarkan Al-Qur'an. Jakarta: Rineka Cipta

Sholeh, Sholeh. (2016). "Konsep Pendidikan Islam yang Ideal: 